\title{
Urban Farming dalam Kampung Vertikal sebagai Upaya Efisiensi Keterbatasan Lahan
}

\author{
Atik Dwi Nur'aini dan Johanes Krisdianto \\ Departemen Arsitektur, Fakultas Teknik Sipil dan Perencanaan, Institut Teknologi Sepuluh Nopember (ITS) \\ e-mail: john_kris@arch.its.ac.id
}

\begin{abstract}
Abstrak - Setiap tahun terjadi peningkatan jumlah penduduk di Kota Surabaya hal ini mengakibatkan penggunaan lahan untuk bangunan terus meningkat karena terjadi peningkatan kebutuhan ruang kota. Tingginya laju pertumbuhan penduduk menimbulkan kebutuhan lahan permukiman yang sangat besar. Seliain itu, penyebab dari padatnya penduduk di Surabaya dikarenakan adanya arus urbanisasi. Masyarakat dari desa berbondong - bondong menuju Surabaya untuk mencari penghidupan yang lebih baik. Sehingga penduduk di Surabaya semakin meningkat setiap harinya. Hal ini mengakibatkan terjadinya keterbatasan lahan untuk area permukiman. Merek akhirnya mendirikan rumah - rumah semi permanen di pusat kota. Aktivitas ini menyebabkan terbentuknya permukiman kumuh di beberapa tempat. Masalah keterbatasan lahan juga banyak terjadi pada sektor pertanian dengan dibukanya lahan pertanian untuk area permukiman maupun area komersil lainnya. Penjabaran di atas melatarbelakangi diperlukannya "Urban Farming dalam Kampung Vertikal Sebagai Upaya Efisiensi Keterbatasan Lahan" yang nantinya diharapkan menjadi tempat tinggal warga kampung yang lebih baik dan meningkatkan tingkat perekonomian mereka. Pendekatan yang dignakan dalam objek rancang ini berupa pendekatan perilaku kampung. Pendekatan ini dipakai dan diterapkan untuk merancang sebuah hunian vertikal yang sesuai dengan perilaku kampung sehingga pengaplikasian arsitektur dengan pendekatan ini akan terlihat pada gubahan massa bangunan, fasad, maupun modul pada setiap unit rumah pada kampung vertikal.
\end{abstract}

Kata Kunci-Kampung, Kepadatan Penduduk, Keterbatasan Lahan, Urban Farming.

\section{PENDAHULUAN}

$\mathrm{P}$ ROPINSI Jawa Timur menempati urutan kedua dengan jumlah penduduk terpadat setelah Propinsi Jawa Barat. Yaitu dengan kepadatan 37,5\% pada tahun 2010. Sedangkan kota dengan penghuni terbanyak di Propinsi Jawa Timur adalah Kota Surabaya dengan jumlah penduduk mencapa 3 juta 170 jiwa pada tahun 2014 [1].

Peningkatan jumlah penduduk ini bertambah dari tahun ke tahun. Pada tahun 2011, jumlah penduduk Surabaya sudah mencapai 3 juta jiwa. Padahal dua tahun sebelumnya jumlah peduduk Surabaya masih berkisar di angka 2,9 juta jiwa. Pada tahun 2006, jumlah penduduk Surabaya adalah 2.784.196. Jumlah ini meningkat di tahun 2007 menjadi 2.829 .552 dan kembali naik di tahun 2008 menjadi 2.903.382. Sementara itu di tahun 2009 adalah 2.938.225, serta di tahun 2010 adalah 2.929.528 [2].

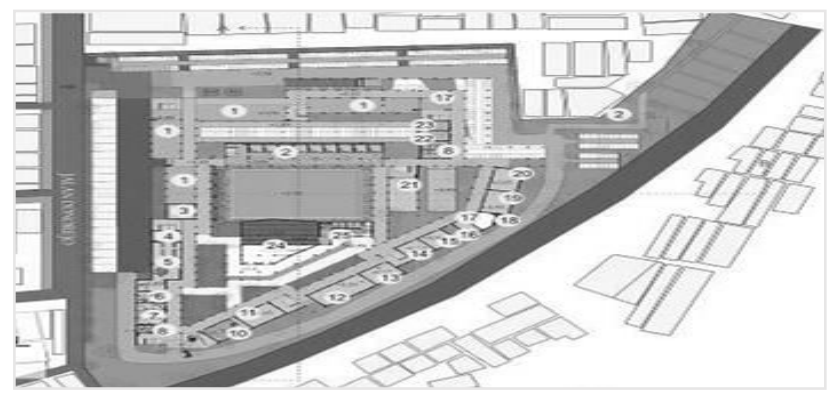

Gambar 1. Peta Peruntukan Kota Surabaya pada Donorejo. (Sumber: dcktr.surabaya.co.id)

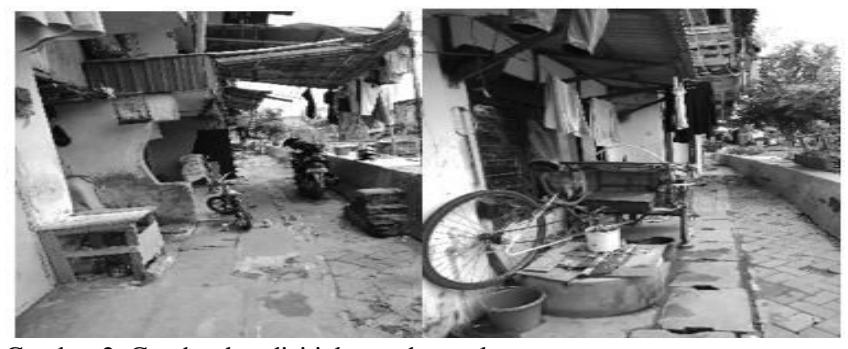

Gambar 2. Gambar kondisi jalan pada tapak.

(Sumber: Dokumentasi Pribadi)

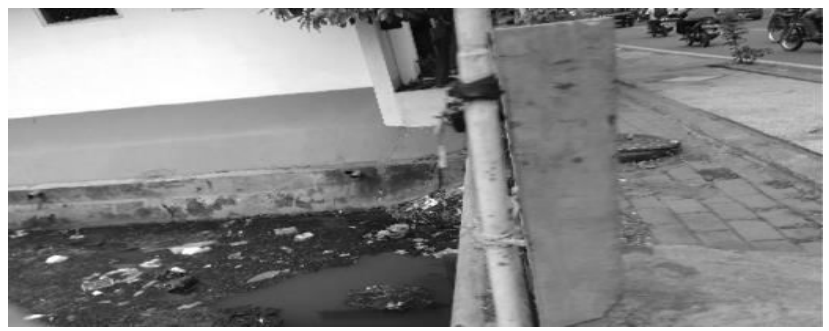

Gambar 3. Gambar kondisi drainase pada tapak.

(Sumber: Dokumentasi pribadi)

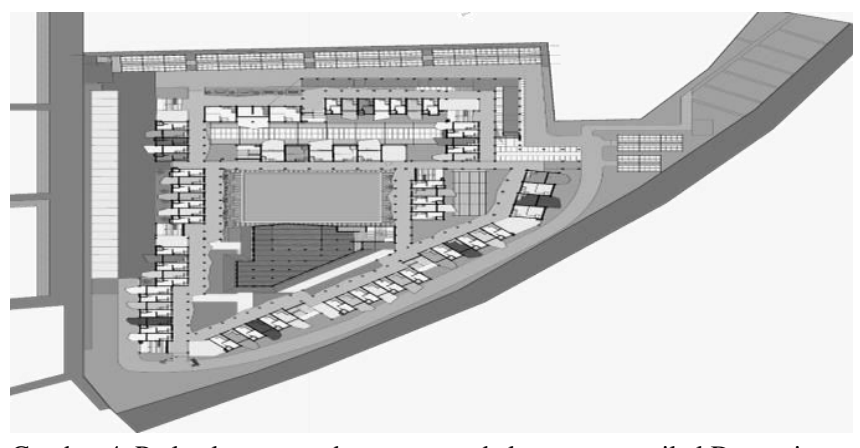

Gambar 4. Perletakan massa bangunan pada kampung vertikal Donorejo. 


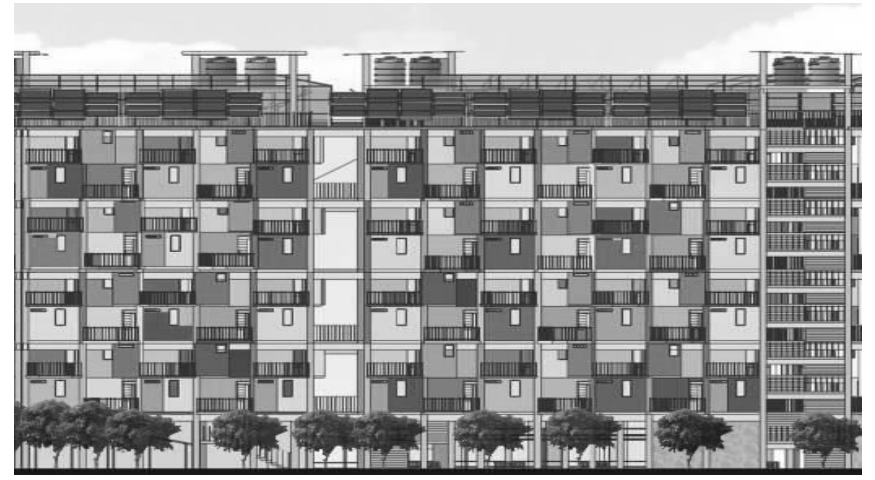

Gambar 5. Bentuk unit yang berbeda pada kampung vertikal Donorejo

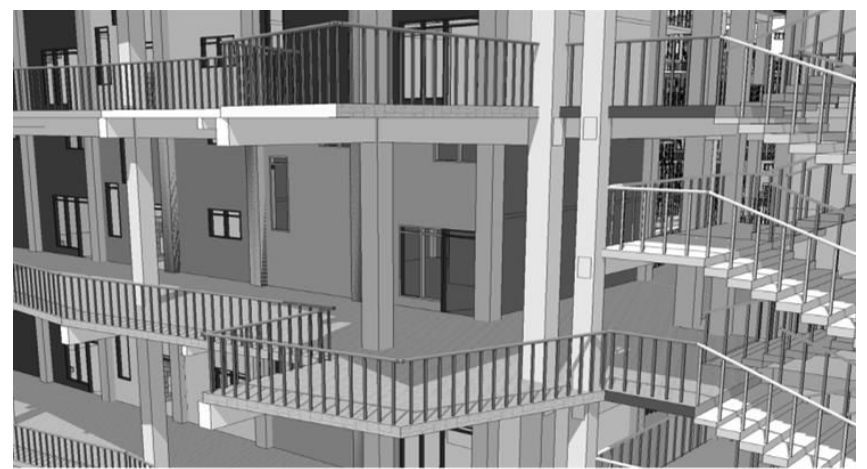

Gambar 6. Selasar yang dinamis pada kampung vertikal Donorejo juga sebagai tempat instalasi urban farming.

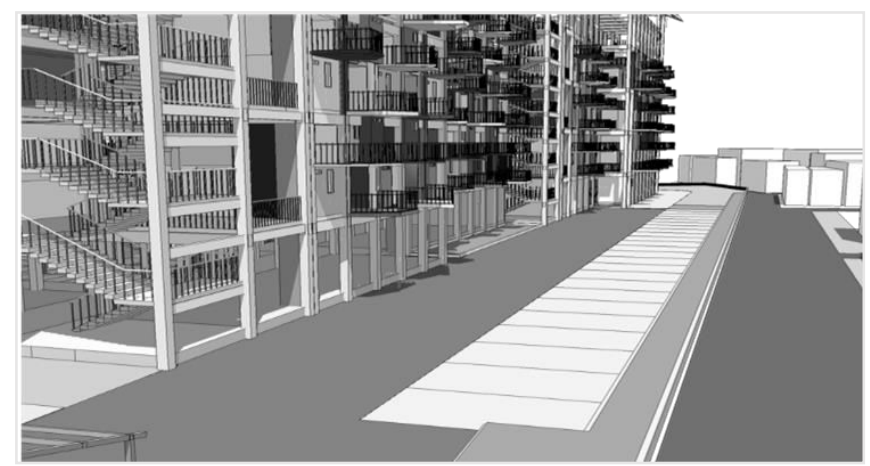

Gambar 7. Setiap unit balkon memiliki bentuk dan ukuran yang berbeda.

Kampung yang akan dijadikan objek rancang berada di Donorejo yang merupakan bagian dari Wilayah Surabaya Pusat. Donorejo masuk dalam Kelurahan Kapasan yang terdapat di Kecamatan Simokerto. Tapak yang diambil berada pada RW VI RT 04, 05, dan 06. Menurut peta peruntukan Kota Surabaya, Donorejo diperuntukkan sebagai area permukiman yang memiliki Garis sempadan bangunan (GSB) sebesar 2-3 m (gambar 1).

Tapak dihuni oleh 890 jiwa. Terdiri dari 471 jiwa laki laki dan 459 jiwa perempuan yang terbagi dalam 286 kepala keluarga. Terdapat kurang lebih 62 lansia dan 82 balita. Sebagian besar masyarakatnya memiliki tingkat pendapatan 800.000-1.400.000 per bulan dengan mata pencaharian di bidang jasa (jasa, tukang, pegawai swasta, dan buruh) [3].

Mayoritas merupakan penduduk asli Surabaya yang pernah menempuh pendidikan hingga jenjang tamat SLTP/sederajat. Area ini memiliki kepadatan penduduk yang tinggi, yaitu 387562 jiwa per Ha, dengan legalitas kepemilikan tanah berupa hak pakai. Bangunan pada area eksisting memiliki kepadatan yang tinggi yaitu >100 rumah per $\mathrm{Ha}$, dengan dominasi konstruksi semi permanen [4].

Utilitas yang ada pada tapak, tergolong kurang baik. Jalan lingkungan yang ada sudah bermaterialkan paving. Namun, jalan tersebut sempit dengan lebar $1 \mathrm{~m}$, ditambah dengan adanya penjual makanan di jalan - jalan (gambar 2). Jalanan juga dipenuhi berbagai material bangunan, ataupun sampah milik warga sekitar. Selain itu, belum terdapat tempat pengelolaan sampah. Sampah banyak ditemukan pada saluran drainase dan sanitasi. Sehingga menjadikan Air dari saluran tersebut menjadi keruh dan kotor disertai dengan bau yang tidak sedap (gambar 3).

\section{METODE PERANCANGAN}

Pendekatan yang digunakan berupa pendekatan perilaku kampung di Donorejo. Pendekatan ini dilakukan dengan melakukan observasi dan wawancara pada tapak. Melakukan pengamatan tentang bagaimana mereka beraktifitas dan berperilaku. Tentang bagaimana karakter kampung tersebut yang kemudian nantinya menjadi acuan penting dalam mendesain kampung vertikal.

Berdasarkan survei yang telah dilakukan, terdapat beberapa aktivitas yang dilakukan oleh warga Donorejo yang telah menjadi kebiasaan atau perilaku mereka setiap harinya. Warga Donorejo merupakan masyarakat dengan tingkat sosial dan kekeluargaan yang tinggi. Saling membantu antar tetangga, saling menyapa dan kompak dalam menjalankan program yang dicanangkan oleh RW setempat. Tingkat sosial yang tinggi ini juga terjadi karena letak rumah mereka yang saling berhimpitan dan sangat dekat. Beberapa dari mereka bahkan meemiliki dapur yang terletak diluar rumah. Gang disekitar tapak juga sempit, selebar $1 \mathrm{~m}$ dan dikurangi dengan benda benda milik warga sekitar. Selain itu, skala dari rumah mereka yang hampir sama dengan manusia membuat perilaku mereka ramah terhadap sesama.

Daerah Donorejo memiliki tingkat usia anak - anak yang cukup tinggi. Banyak anak usia sekolah dasar di sana. Sepulang sekolah mereka akan bermain bersama di jalan Donorejo yang lebih lebar. Hal ini mereka lakukan karena tidak adanya fasilitas ruang terbuka yang tersedia. Rumah mereka juga terlalu sempit untuk dijadikan tempat bermain. Sedangkan untuk ibu - ibu rumah tangga, banyak dari mereka yang tidak bekerja. Selama di rumah, mereka akan mengerjakan pekerjaan rumah tangga dan bersosialisasi dengan tetangga. Sedangkan untuk lansia, setiap hari sabtu diadakan pengecekan kesehatan oleh RW setempat. Meskipun mereka tetap ikut keluarga masing - masing, namun para lansia ini tetap mendapatkan perhatian lebih oleh RW.

Metode desain yang digunakan berupa metode pengumpulan data yang terdiri dari pengumpulan data primer dan pengumpulan data sekunder. Data primer berupa observasi terhadap tapak yang akan dijadikan sebagai kampung vertikal dan wawancara kepada warga atau masyarakat kampung donorejo. Sedangkan data sekunder berupa studi literatur, dan studi preseden. 


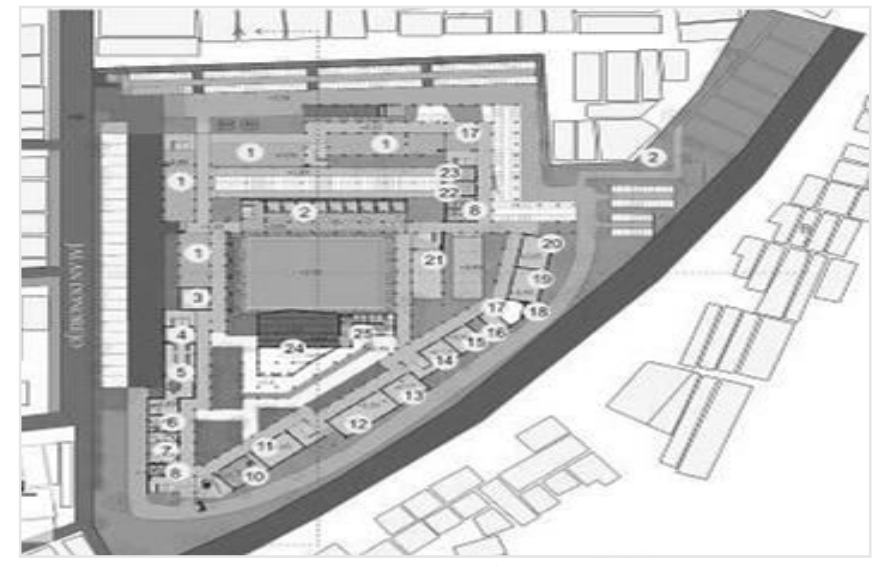

Gambar 8. Lantai dasar digunakan sebagai fasilitas umum.

\section{HASIL DAN EKSPLORASI}

Perancangan objek ini bertujuan untuk menbangun kampung vertikal yang adaptif terhadap perilaku warga kampung Donorejo. Sehingga kampung vertikal Donorejo diharapkan dapat menghadirkan suasana dan kehidupan kampung sebagaimana sebelumnya namun dengan kualitas hidup yang lebih baik. Tujuan yang kedua berupa menerapkan Urban farming yang merupakan pertanian kota pada lahan sempit sebagai upaya mengatasi menipisnya lahan pertanian. Urban farming diharapkan mampu memenuhi kebutuhan sayur dan buah bagi warga kampung sendiri dan juga mampu meningkatkan ekonomi warga kampung Donorejo dari hasil kegiatan urban farming.

Kriteria desain yang harus dicapai adalah.

1.Desain bangunan mampu merepresentasikan karakter dan perilaku masyarakat kampung Donorejo yang memiliki kekeluargaan tinggi antar tetangga dan intensitas interaksi sosial yang tinggi

2.Fasilitas umum yang disediakan harus mampu mewadahi segala kegiatan yang dibutuhkan oleh warga kampung Donorejo.

3.Setiap unit pada bangunan kampung vertikal memiliki ruang untuk melakukan urban farming yang mudah dirawat dan dapat dilakukan oleh semua penghuninya.

4.Hasil Urban farming memiliki nilai jual yang tinggi seingga mampu meningkatkan ekonomi penghuninya.

5.Desain harus lebih baik dari kondisi eksisting, mampu meningkatkan kualitas hidup warga kampung Donorejo serta dapat memberi kontribusi positif terhadap Kota Surabaya.

6.Penataan ruang harus efisien guna memaksimalkan fungsi ruang karena keterbatasan lahan.

Massa bangunan utama didapatkan dengan mempertimbangkan aspek pencahayaan alami. Kampung vertikal akan dijadikan sebagai sarana urban farming, maka cahaya matahari memiliki peran penting dalam pertimbangan desain. Oleh karena itu, bentuk massa utama mengikuti alur tapak dengan beberapa patahan untuk menghadirkan kesan dinamis dan tidak monoton (gambar 4)

Bentuk dari unit hunian berbeda satu sama lain. Karena setiap hunian di kampung berbeda dan memiliki ciri khasnya masing masing. Rumah adalah identitas penghuninya. Unsur pembeda yang digunakan pada desain berupa bentuk balkon,

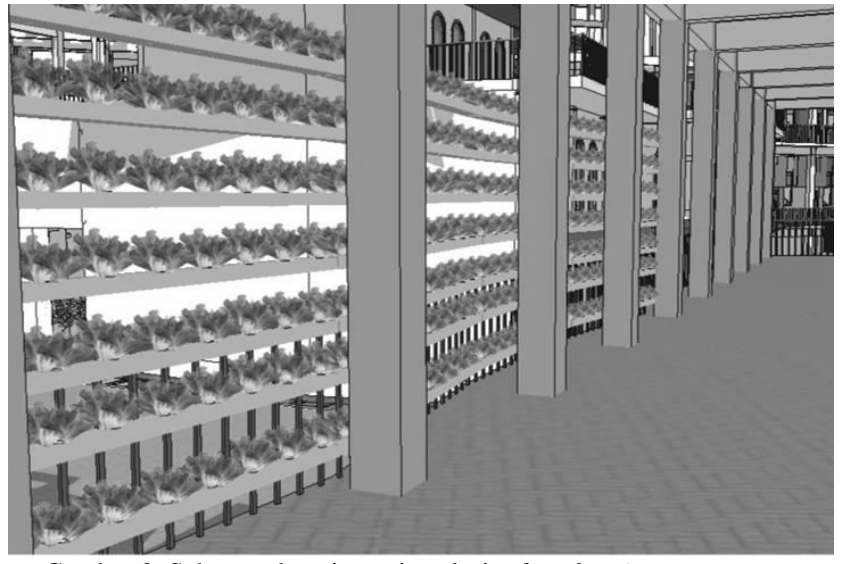

Gambar 9. Selasar sebagai area instalasi urban farming.

selasar, warna dan bentuk dari bukaan (gambar 5 dan 6).

Setiap unit memiliki balkon yang disusun secara zig-zag, sehingga memungkinkan warga kampung Donorejo untuk berinteraksi dan bersosialisasi dengan tetangganya. Tidak hanya kiri dan kanan, tetapi juga dengan tetangga di atas dan bawah unitnya (gambar 7).

Seluruh lantai dasar digunakan sebagai fasilitas umum. berupa fasilitas niaga, fasilitas kesehatan, fasilitas pendidikan, Masjid, tempat parkir, dan ruang terbuka hijau. Lanatai dasar merupakan pusat penjualan hasil urban farming oleh warga kampung Donorejo (gambar 8). Mereka menanam tanaman pada tempat yang telah disediakan, kemudian dapat menjualnya di lantai dasar. Setiap lantai pada bangunan kampung vertikal Donorejo terdapat ruang terbuka yang digunakan sebagai sarana sosialisasi bagi warga kampung. Juga sebagai tempat melakukan aktivtas bersama yang rutin dilakukan. Selain itu, ruang terbuka tersebut juga digunakan sebagai area bermain untk anak - anak.

Setiap unit memiliki ruang untuk melakukan aktivitas urban farming yang terletak pada selasar dan balkon. Selasar memiliki lebar $3 \mathrm{~m}$ yang memungkinkan untuk melakukan urban farming dengan sistem hidroponik (gambar 9). Instalasi urban farming juga berfungsi sebagai pembentuk fasad dan sebagai sun-shading untuk bangunan.

Sistem urban farming yang akan diterapkan pada rancangan berupa sistem vertikultur. Vertikultur adalah sistem budidaya pertanian yang dilakukan secara vertikal atau bertingkat, baik indoor maupun outdoor. Vertikultur dapat meningkatkan hasil pertanian hingga sepuluh kali lipat bahkan lebih. Sistem ini merupakan pemanfaatan lahan sempit dengan seoptimal mungkin, sehingga lahan sempit yang tidak produktif dapat dimanfaatkan untuk produksi pertanian. Pada umur 50 hari tanaman sudah bisa memetik hasil panen sayuran, dan selang 1-7 hari kemudian dapat dilakukan panen kedua [5].

Sistem vertikultur menggunakan konsep hidroponik dengan jenis Deep Flow Teqnique System (DFT) (gambar 8). Yaitu hidroponik yang menggunakan sistem aliran air, dalam memenuhi nutrisi tanaman. Sistem ini menggunakan tenaga listrik, untuk mengalirkan air pada tanaman. Air akan mengalir pada instalasi dan mengenai seluruh akar tanaman, kemudian kembali ke tandon. Air mengalir secara berkala dengan bantuan timer yang telah dipasang.

Sistem DFT lebih mudah dalam perawatannya, dan tidak memerlukan material yang mahal. Tanaman akan diletakkan 
disepanjang koridor rumah susun. Perletakan ini juga akan membuat kualitas udara disekitar rumah susun menjadi lebih baik. Tanaman ditanam secara horizontal dan bertingkat. Jarak perletakan tanaman dalam instalasi (pipa) adalah $30 \mathrm{~cm}$. Jadi, sepanjang $3 \mathrm{~m}$ Pipa instalasi secara horizontal dapat ditanami sebanyak 10 tanaman. Sedangkan pipa instalasi bertingkat delapan ke atas. Jadi setiap unit koridor Rumah susun dapat menghasilkan 80 batang tanaman (selada) setiap bulannya. Sehingga dalam satu bulan koridor rusun dapat menghasilkan minimal $80 \times 79 \times 4$ (unit ) $=25.280$ batang tanaman hidroponik.

Tabel 1.

Daftar hasil panen tanaman hidroponik kampong vertical Donorejo dalam satu periode panen

\begin{tabular}{|l|l|l|}
\hline No & Tanaman & Hasil Panen \\
\hline 1 & Selada $200 \mathrm{gr} /$ batang & $5.056 \mathrm{~kg}$ \\
\hline 2 & Sawi $250 \mathrm{gr} / \mathrm{batang}$ & $6.320 \mathrm{~kg}$ \\
\hline 3 & Kailan $650 \mathrm{gr} /$ batang & $16.432 \mathrm{~kg}$ \\
\hline
\end{tabular}

Tabel 2.

Jenis tanaman yang dapat ditanam dengan hidroponik di Indonesia

\begin{tabular}{|l|l|c|}
\hline No & Tanaman & Waktu Panen (bulan) \\
\hline 1 & Cabai besar & 2 \\
\hline 2 & Cabai rawit & 2,5 \\
\hline 3 & Terong & $3-4$ \\
\hline 4 & Mentimun & $2-3$ \\
\hline 5 & Tomat & 2.5 \\
\hline 6 & Kacang panjang & $3-4$ \\
\hline 7 & Buncis & 2 \\
\hline 8 & Paprika & 3 \\
\hline 9 & Bayam & 1 \\
\hline 10 & Kangkung & 1 \\
\hline 11 & Selada & $1-1.5$ \\
\hline 12 & Seledri & $1-3$ \\
\hline 13 & Bawang daun & 2,5 \\
\hline 14 & Pakcoy & 1,5 \\
\hline 15 & Kailan & $1-1,5$ \\
\hline 16 & Bunga kol & 3 \\
\hline 17 & Brokoli & $2-3$ \\
\hline 18 & Bawang merah & $2-3$ \\
\hline 19 & Bawang putih & $3-4$ \\
\hline 20 & Bawang bombay & $4-5$ \\
\hline
\end{tabular}

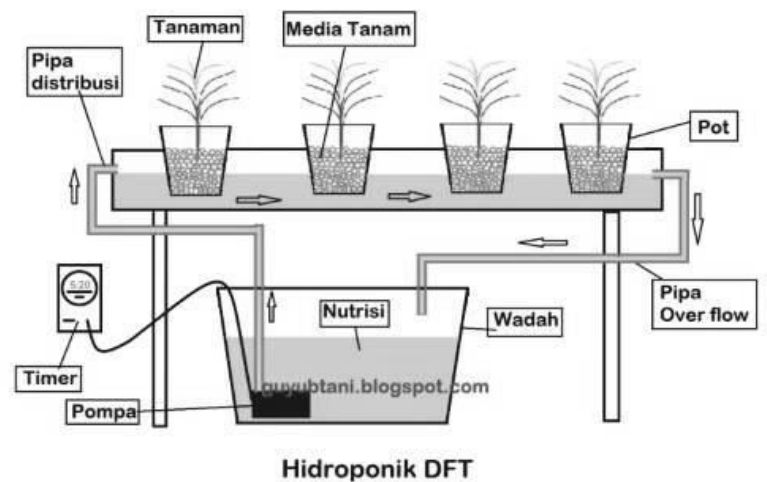

Gambar 10. Sistem urban farming yang digunakan pada kampung vertikal (Sumber: guyubtani.blogspot.com).

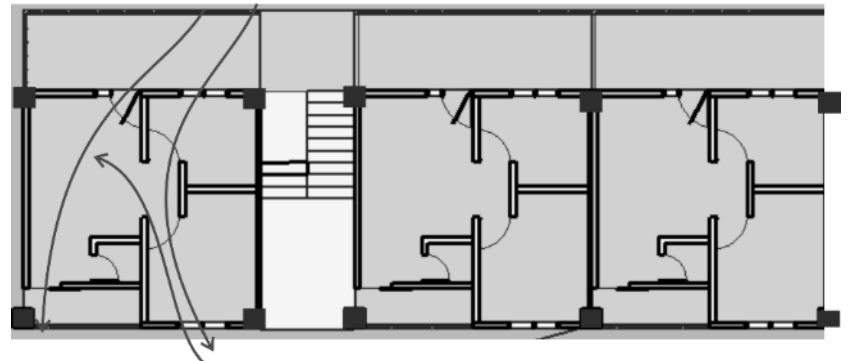

Gambar 11. Skema ventilasi, pencahayaan serta penghawaan pada bangunan.

Dengan hasil tersebut, maka setiap bulannya kampung vertikal pada bagian koridor akan panen tanaman hidroponik dengan hasil yang cukup (tabel 1). Terdapat beberapa jenis tanaman yang dapat dibudidayakan menggunakan sistem hidroponik di Indonesia. Tanaman yang paling sering dibudidyakan diantaranya adalah selada, dan jenis sawi sawian (tabel 2).

Peningkatan kualitas kampung lebih ditekankan pada aspek lingkungan. Kondisi lingkungan tapak eksisting tidak begitu baik seperti yang telah disebut di atas. Peningkatan ini dilakukan dengan cara perbaikan aksesibilitas, struktur, utilitas, dan kesehatan lingkungan yang meliputi pencahayaan, penghawaan, dan pengelolaan sampah (gambar 9 dan 10).

Kontribusi yang diberikan oleh objek rancang pada Kota surabaya berupa pengurangan limbah yang dihasilakan oleh bangunan. Limbah telah terolah dan digunakan kembali. Kontribusi lainnya yaitu kampung vertikal Donorejo mampu menyediakan hasil pertanian yang dapat dinikmati oleh warganya sendiri maupun warga sekitanya yang merupakan area permukiman. Selain itu, Objek rancang dapat menghasilkan energi listrik sendiri karena memanfaatkan energi matahari sebagai sumber listrik. Sehingga pemerintah kota tidak perlu menyediakan aliran listrik dengan jumlah yang banyak.

Penataan ruang yang efisien dilakukan dengan membuat sekat yang tidak permanen pada unit kampung vertikal. Sekat ini dapat bergeser atau moveable sehingga memungkinkan untuk melakukan penataan ruang sesuai dengan keinginan pengguna. Ruang bawah tangga juga dimanfaatkan maksimal sebagai tempat penyimpanan sehingga tidak ada ruang yang terbuang sia - sia (gambar 11).

\section{KESIMPULAN/RINGKASAN}

Solusi terbaik untuk mengatasi keterbatasan lahan akibat jumlah penduduk yang terus meningkat adalah dengan melakukan pembangunan secara vertikal. Pembangunan secara vertikal akan meningkatkan jumlah jiwa yang dapat ditampung dalam suatu bangunan. Pembangunan secara vertikal juga akan mengurangi building coverage di muka bumi, sehingga lahan yang tersisa dapat digunakan sebagai ruang terbuka hijau.

Maka dirancanglah kampung vertikal Donorejo sebagai upaya efisiensi keterbatasan lahan. Kampung vertikal Donorejo dirancang berdasarkan studi perilaku yang telah dilakukan pada masyarakat Donorejo. Oleh karena itu, kampung ini berbeda dengan kampung lainnya juga berbeda dengan rumah susun. Dengan adanya kampung vertikal 
Donorejo yang baru, diharapkan dapat memperbaiki kualitas hidup warganya. Karena kampung ini memiliki tingkat kesehatan yang lebih baik, lingkungan yang lebih baik, serta modul yang lebih tertata, namun tidak meninggalkan kesan dari karakter kampung.

Selain itu, urban farming didalamnya dirancang untuk mengatasi isu keterbatasan lahan pertanian. Juga untuk meningkatkan tingkat ekonomi warga Donorejo. Urban farming ini sangat strategis dan tepat diaplikasikan pada kampung Donorejo karena letak kampung yang berada di pusat permukiman dan dekat dengan pusat pertokoan. Sehingga dapat dengan mudah dijangkau oleh masyarakat sekitar.

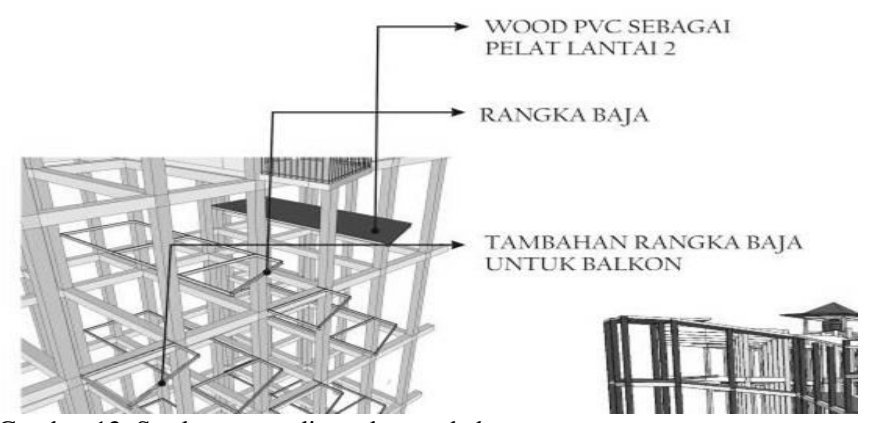

Gambar 12. Struktur yang digunakan pada bangunan.

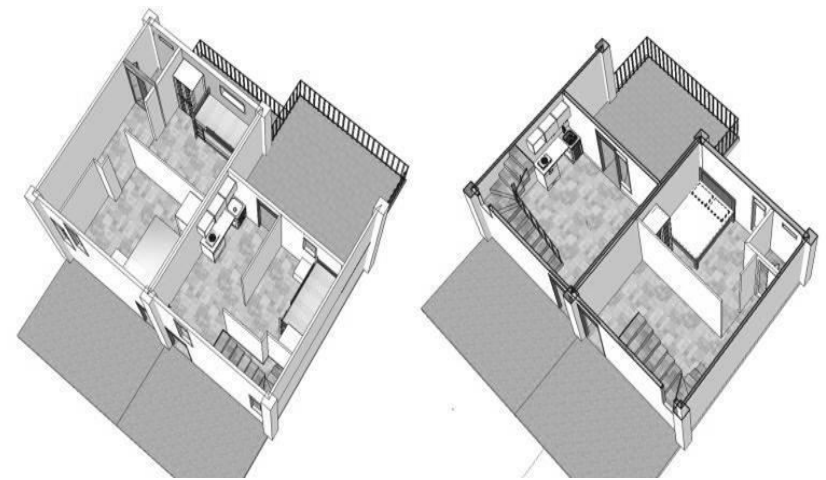

Gambar 13. Rancangan unit pada kampung vertikal Donorejo.

\section{DAFTAR PUSTAKA}

[1] Dispenduk Capil Surabaya, "Dispenduk Capil Surabaya," Surabaya, 2016.

[2] H. Pramono, "Penduduk Surabaya Lewati 3 Juta Jiwa," tribunnews.com, Surabaya, 2016.

[3] Anonymous, "Rekapitulasi Base Line 100-0-100 RW VI Kelurahan Kapasan Tahun 2015," Surabaya, 2015.

[4] E. Barbara, Patrica Bela. Ummilia, "Clustering Permukiman Kumuh di Kawasan Pusat Kota Surabaya," J. Tek. POMITS, vol. 3, no. 2, 2014.

[5] Anonymous, "Urban Agriculture What and Why," 2016. [Online]. Available: www.ruaf.org. 